\title{
ASSASSINATION: A BRIEF EXEGESIS
}

\section{Paul Boboc}

The noun assassination first appeared in print in Shakespeare's Macbeth, written in 1606 and published in the First Folio in 1623. The Oxford English Dictionary defines Shakespeare's use of the word essentially as we do: "[ $\mathrm{t}]$ he action of assassinating; the taking the life of any one by treacherous violence, esp. by a hired emissary, or one who has taken upon him to execute the deed" ("assassination," n.d.). Its history as a noun may evidently be traced to S. Patericke, an English author (also according to the $O E D$ ); Shakespeare simply added the French suffix -ion to the already existing word. The $O E D$ defines Patericke's use of assassinate as: "[m]urder, or an assault with intent to murder, by treacherous violence; assassination" ("assassinate," n.d.). Interestingly, as per the $O E D$, assassinate did not acquire its current status as a verb until Bolton's Roman Histories, published in 1619; such a use would have derived from its former currency as a noun and likely revealed knowledge either of Shakespeare and Patericke's work or reflected the independent linguistic coinages so prevalent in renaissance England.

Shakespeare's use of the word occurs in Act 1, Scene VII of Macbeth, which he wrote after Hamlet and Othello and at approximately the same time as King Lear; by the time he wrote the "scottish play" he had attained full artistic maturity. The word is found in a famous soliloquy:

If it were done when 'tis done, then 'twere well

It were done quickly: if the assassination

Could trammel up the consequence, and catch

With his surcease success... I.vii 1-4

The rhetorical effect of placing assassination a foreign, exotic-sounding fivesyllable word, after a line and a half of almost entirely (13 of 14) monosyllabic words, suggests Shakespeare's adroitness at inventing and adapting words to suit his dramatic and psychological conceptions. One can imagine the quickness of Macbeth's thoughts as he contemplates the murder-thoughts that ultimately slow into the long and serpentine enunciation of assassination, which breaks the iambic flow of the line.

In modern culture, the word assassination is commonly used to refer to the violent murder of high-profile officials. The World English Dictionary emphasizes this aspect, defining assassinate as "to murder (a person, esp. a public or political figure), usually by a surprise attack" ("assassinate," n.d.). The relationship between the word assassination and the stealthy slaughter of significant persons has its origins in medieval lore. According to the Western imagination (and hundreds of years of fanciful reimaginings of Islamic civilization), assassins during the Crusades were Muslims called upon by their local chieftain to kill off prominent Christians (an act which, of course, entailed certain death if discovered, and often intense torture). According to an interpretation of history (which most modern scholars call into question) assassins would arrest the fear of death and the anxiety associated with murdering the enemy in his own camp by consuming a mix of hashish and marijuana before assassinating their victims. Consequently, the words assassin, assassination, and assassinate, all come from the Arabic root word for "hashish-user." In truth, the assassins were a particularly fanatical 
branch of Ismaili Shia's who threatened the authority of Seljuk Sunnis, founded by Hassan I Sabbah around 1100. The "hashish" association was probably derogatory, originating from rumors invented by the assassins' enemies (Szczepanski, n.d.).

The history of assassination since Shakespeare's day has been essentially unchanging, with writers taking their cue from Shakespeare's use. However, the current dictionary definition differs slightly from that of the $O E D$. Indeed, dictionary.com emphasizes that assassinations are usually of "a politically prominent person," whereas, according to the $O E D$, it is the killing of "anyone," in which case it's poorly differentiated from its sibling word murder. The latter meaning has taken precedence; to use a popular source as an example, the Wikipedia article on JFK talks about his "assassination," and Lincoln's murder is also commonly called an assassination, whereas the Sharon Tate article refers to her "murder" by Manson's followers. The United States House Select Committee on Assassinations, established in 1976, investigated the JFK and MLK assassinations, whereas nobody says that Zimmerman assassinated Trayvon Martin. Indeed, a Google Book search of "assassination" mostly references Lincoln and Kennedy, and one result references Marat- also an important political figure. Thus, owing to its root in relation to the "hashashins" who killed high-profile figures, assassination has recently been (generally) related to significant public individuals, though Shakespeare's use may not have had such a narrow definition in mind; the sound qualities and connotations of the word seem to have interested him more.

Most of the Google search results have this definition in mind, but one stands out: the Obama administration's "presidential assassination program," which several sites call attention to. As with Shakespeare, who uses "assassination" in Macbeth to augment the psychological impact of Macbeth's speech, Obama's detractors use the word "assassination" to refer to Obama's (misinterpreted) plan. The word has become, it seems, an even more powerful word in the public imagination than "killing" or "murder," perhaps because of its association with significant people and political power. The word has thus remained more or less unchanged since its initial use in the $1600 \mathrm{~s}$, but its existence as a word apart from "murder" bears witness to how people differentiate different kinds of murder, associating the murder of high-profile individuals, and murder by stealthy means, with a kind of stigma particular to itself.

To conclude, the word assassination and its sibling words assassin and assassinate continue to have a powerful allure that is likely to go on, as long as political contention continues. Indeed, their allure seems to come from their being related in the public imagination to clandestine murders of important individuals. In this sense, assassinations threaten to disrupt the public peace and order to an extent that normal murders often do not. Along with "swagger," another alluring Shakespearean coinage, it may be one of the most interesting words Shakespeare popularized and brought into the popular imagination, and with far less terrible misuse to boot.

\footnotetext{
${ }^{1}$ According to dictionary.com, "swagger" is first recorded in A Midsummer Night's Dream III.1.79, and defined as "To walk or strut with a defiant or insolent air." The current "swag" originates in the Shakespearean coinage.
} 


\section{WORKS Cited}

assassination, n.. (n.d.). : Oxford English Dictionary. Retrieved March 12, 2014, from http://www.oed.com/view/Entry/11735?redirectedFrom=assassination\#eid

assassin, n.. (n.d.) Oxford English Dictionary. Retrieved March 12, 2014, from http://www.oed.com/view/Entry/11728?redirectedFrom=assassin

assassinate, v.. (n.d.) Oxford English Dictionary. Retrieved March 12, 2014, from http://www.oed.com/view/Entry/11733

Szczepanski, K. (n.d.). History of the Assassins or Hashshashin. About.com Asian History. Retrieved March 11, 2014, from http://asianhistory.about.com/od/iran/p/assassinsprofile.htm

https://www.google.com/search?q=assassinaton\&ie=utf-8\&oe=utf$8 \&$ aq $=$ t\&rls=org.mozilla:en-US:official \&client=firefox $\mathrm{a} \&$ channel $=\mathrm{sb} \#$ channel $=\mathrm{sb} \& \mathrm{q}=$ assassination $\& \mathrm{rls}=$ org.mozilla:en-US:official

Definition of assassinate in English:. (n.d.). assassinate: definition of assassinate in Oxford dictionary (British \& World English) (US). Retrieved March 12, 2014, from

http://www.oxforddictionaries.com/us/definition/english/assassinate?q= assassinate

Swagger. (n.d.). Dictionary.com Unabridged. Retrieved July 20, 2014, from Dictionary.com website: http://dictionary.reference.com/browse/Swagger 